\title{
The Relationship of Consumer Perception of Muslim Students on Label Food Products Packaging with Their Purchase Decision Making
}

\author{
1Yulia Rahmawati, 2 Muktiarni \\ 1,2Universitas Pendidikan Indonesia, Bandung, Indonesia \\ 1yuliarahmawati@gmail.com, ${ }^{2}$ muktiarnni@gmail.com
}

\begin{tabular}{|c|c|}
\hline Article Info & bstract \\
\hline $\begin{array}{l}\text { Article History } \\
\text { Received: July 12, } 2018 \\
\text { Accepted: September 30, } \\
2018\end{array}$ & \multirow{2}{*}{$\begin{array}{l}\text { This research is motivated by the problems of food technology that has been } \\
\text { growing rapidly at today, including the use of ingredients, which is the vital } \\
\text { thing to be considered in its preparation. For Muslim community, the } \\
\text { problem that arises is the number of food ingredients, both the main raw } \\
\text { material and the additive material, which are difficult to trace their origin, } \\
\text { whether they are from halal sources or not. There is also a public perception } \\
\text { concerning the clarity or label of halal food products purchased. It would } \\
\text { impact the decision purchase of food product. This study used a case method } \\
\text { using questionnaire for Moslem students in UPI Department of Culinary } \\
\text { Study Program. Correlational analysis was done to find the correlation of } \\
\text { conception on label food with purchase decision making. The result shows } \\
\text { that there is a sifnificant correlation between both respondents or } \\
\text { consumers' conception on label information of food ingredients and their } \\
\text { purchase decision making. This is evident in the correlation which indicates } \\
\text { the presence of a significant relation (r=0,546). It could be recomended that } \\
\text { in any attempt to produce food, especially in Indonesia, food ingredients in } \\
\text { terms of being halal and hygienic should be highly considered; therefore the } \\
\text { producers should have a halal certificate of the authorities, which in this case } \\
\text { Board of Indonesian Muslim Scholars (MUI). }\end{array}$} \\
\hline $\begin{array}{llr}\text { Keywords } & & \\
\text { Conception of } & \text { Moslem } \\
\text { Consumers; Halal Food } \\
\text { Certificate; } & \text { Product } \\
\text { Purchase Decision } & \end{array}$ & \\
\hline & \\
\hline
\end{tabular}

\section{INTRODUCTION}

Food is one of primary needs for living things, chiefly of human beings. A human being, as other living organisms of getting their energy source to run activities are to be implemented from food which is carried by they consumed. The human body nutritional intake need to continue running their activities well. The increasing human population, already will impact on the availability of food, so many parties tried to develop and producing many kinds of food from various materials, both natural or unatural ingredients to be able fulfilling the demands of the need for food.That is why, there're a lot of the types of food that process at local industry centres food and packed in such a way, so that it can produce food in numbers and long enough.

Food industry development having strategic positions in the national economic growth in Indonesia. Until 2013, this industry have contributed income gross domestic product (GDP) of 7,42 \% with the IDR 674,3 billion and the number of its export reached $6 \%$ of the total Indonesia exports.

The food industry development was supported by increased per capita consumption as a result of an increase in the number of people who has been increased with a population growth $1.4 \%$ per year. In 2030, it is estimated that indonesia would suffer the increasing number of population become 300 million people therefore it would be 
the market that have been getting lured in the business of food (Hanifawati and Suryantini, 2015, p. 1).

Many kinds of food that develops today can be obtained in the market, ranging from sweet to sour food are everything packed and served in attractive form.

It cannot be refuse that preparing and appearance of food is an important role in marketing a food products, both instant and packaged food. That some say "people eat with the eyes not with the mouth". It is related to the understanding the qualities of meal itself.

Along with it, public awareness of the quality of food consumed is increased, especially in terms of nutrition and health food. There're many countries in the world that obliges every food industry to include the information keys of food on its package that has already been stated by Talati, et.al (2017, p. 1):

In many countries, the provision of nutrition information on packaged foods is mandated by governments or voluntarily applied by food manufacturers. The Nutrition Facts Panel (NFP), the most commonly applied form of nutrition information, comprehensively lists the amounts of positive and negative nutrients within a product. In some countries, front-of-pack labels (FoPLs) that present a simplified version of the information contained in the NFP are also provided.

It is not just the quality of nutrition and health that is continuously being attentive, especially in Indonesia, but is also related to halal or haramof food that sold based on placed their trust in the Islam, where majority of Indonesia people are moslem. This is revealed by Zulaekah dan Kusumawati(2015, p. 25-26):

Muslims are taught to eat health and good food. Islam take special care and cleanliness how to cook food, serving, manner of feeding until on how to throw the rest of the food. The haram food have wisdom hidden.

That is why, any packaged food that be distributed in market especially in Indonesia, In addition to informthe content and nutrients and the expire date, it must be required to include a halal certificate logo which means that the food has been tested by MUI for examination of halal in accordance with the manner of Islam, so it can be consumed by muslims.

The problems that appear in selection of many kinds of food in Indonesia today is attention to label food itself. There are still many people are more likely to see the brand than the key information around food to be known.For that reason, the government should pay attention to the problems this halal certificate. It was revealed in Aslan and Aslan research (2016, p. 16):

...not having a global Muslim halal certification head cause to many different halal standards around the world. Excluding Malaysia and Indonesia, many Muslim governments do not make great supports for halal certification and awareness. The logic behind these banns is to protect health of people and environment. There is an urgent need for a head of Muslim halal standards like ISO otherwise Muslims consumption habits and religious differences can be used in bad faith and force them to eat haram foods.

Meanwhile, in the educated community, is generally tending to see information of nutrition and health food itself.So that their decision to purchase a foods product more determined by their own perceptions on the brand and nutrition of food than the halal of it.Relating to how a perception tendency of muslem students as any one group the muslim community highly educated in choose the food, it would have to do is considered the research which is quite deep.These matters become attraction to assess and check on the relationship between perception of muslem students to halallabel of food with the purchase decision. 
For that reason, a problem which was formulated in research is what is the relationship between the perception of muslem students to halallabel of food with the purchase decision at Department of Culinary Study Program of UPI?

\section{METHOD}

In keeping with the central theme of research whis is The Relationship of Consumer Perception of Muslim Students on Label Food Products Packaging with Their Purchase Decision Making on Students of Department of Culinary Study Program of UPI, so the approach that is used is the one shot case study approach which is focused to examine a cases events on a particular subject with one times data collection (Arikunto, 2010, p. 124).

This approach had been designed in quatitative research design which is the collected data would be computed by statistical test system to obtain the answer and conclusion of the problem.

Meanwhile, the subjects or participants as the research population are focused on students of UPI Department of Culinary Study Program as many as 55 moslem students.

In accordance to the researchdesign, data collection that be done in this research is distribute the Likert scale questionnaires, that be included some statement which is categorized into two groups of variable, perception students on halalfood products label and food product purchase decision. Meanwhile, the analysis technique that be applied to assess relatinship between the both variables is product moment correlation test (Sugiyono, 2012, p. 153).

\section{RESULT}

The assessment of the customers to informations on the package of food product done as preference of consumers on that product. The main informations of this related to nutritions, ingredients, and the halal certificate always be considered by consumers, especially moslem consumers.

Based on this research, the respondents seemed understand that any food they consumption shall things that are halal according to syariah of Islam. It can be seen that the majority of respondents $(92,7 \%)$ said thatthe essential point of the food that they consumption is food expressed halal.

The halal of food, especially food in the pack that they choose, in general $(82.7 \%)$ they knew that there is a halallogo which has issued by Majelis Ulama Indonesia (MUI)as an institution which has authority to issue a halal certificate for every food products in Indonesia.

In addition to the halalof products, respondents would always see the information of the composition/substances which is in the labeling food products package, which are more than half of respondents $(65,5 \%)$ were focusing their attention to this thing,although they are still quite a lot of them (34,5\%) which was not so will lay it to their heart.

It is estimated that because they are quite great deal of trouble to understand the complex terms that used to describe a material at a food product pacjage. Regarding this, more of them $(90,9 \%)$ stated that the complex termsthat used to describe a material at food products package was hard to understand. However, most of them $(92,7 \%)$ understand that the ingredients that used in a product pacjage reflects the food safety and has a quality of halal.

The attention of the respondents who have enough good about informations on the package in order to information of halal, shows that basically, the respondents have own perception a fairly high to the health, security, and halal of food products that will 
they consumption.This is in accordance with the opinions of Mohamad andBackhouse (2014, p. 694) who state thata thing to be observed in food was halal, hygienic, and legal.

The reality of high perceptions of respondents to the information of substances and halalon the food package is certainly has had an impact ontheir purchase decision to buy and consume the product. This can be seen from the majority of respondents $(98,1$ $\%$ ) who stated that the ingredients are written in a label on a package is the considerations being the fact to choose and purchasethe food products in package.

The same thing happened to the halal food products, where most of respondents (98.2\%) stated that they would decide purchase the food products which has halal label on its package. This is in line with a view of Kotler (2003, p. 196) who suggested that thedecision to buy of the consumer is a decision about the kind of product, in this case, the consumers can decide about what product are purchased to meet and satisfactory needs.

Here apparent that they have had a relationship of correlational between the perception of respondents about the information of substances and halal certificate on the food packagewith a decree of the purchase of food products.This is proven by the results of the test and been approved a correlation in which shows that there has been a significant relation exists $(r=0,546)$ between the perception of the additional information on the food packagewith the decision of the purchase of food products.

\section{CONCLUTION}

Based on of discussion to be addressed that were analyzed, it can be concluded that the respondents perception as moslem consumers to the information on food package have a significant correlation to their purchase decision to buy the food.This is apparent from the high of their perception towards any information stated around the food and strong their decisions to choose the types of food products that healthy and halal.

For that reason, it can be recommended that in the efforts to grow food production, especially in Indonesia, both by high industries or home industries,

The most important thing is the use ingredients that should be given to a hygienic and halal, including in the making process, and always to gain the halal certificate from the autority institution, that in this case is MUI.

\section{REFERENCE}

[1] Arikunto, S.(2010)Prosedur Penelitian-Suatu Pendekatan Praktik.Jakarta: PT. Rineka Cipta.

[2] Aslan, I. and Aslan, H. (2016) Halal Foods Awarness and Future Challenges. British Journal of Economics, Management \& Trade. Vol. 12 (3). pp. 1-20.

[3] Hanifawati, T. and Suryantini, A. (2015) Pengaruh Atribut Kemasan Makanan Ringan terhadap Proses Pengambilan Keputusan Pembelian Konsumen. Prosiding Seminar Nasional Multi Disiplin Ilmu \& Call For Papers Unisbank (Sendi_U). Kajian Multi Disiplin Ilmu untuk Mewujudkan Poros Maritim dalam Pembangunan Ekonomi Berbasis Kesejahteraan Rakyat. ISBN: 978-979-3649-81-8.

[4] Indrawati, D. (2017) Pengemasan Makanan. Ponorogo: Forum Ilmiah Kesehatan (FORIKES).

[5] Kartikasari, D., Arifin, Z., and Hidayat, K. (T.thn.) Pengaruh Perilaku Konsumen terhadap Keputusan Pembelian (Penelitian pada Mahasiswa Administrasi Bisnis Angkatan 2012/2013 Fakultas Ilmu Administrasi Universitas Brawijaya yang Mengkonsumsi Produk Mie Instan Merek Indomie). Dipetik (online) pada tanggal 28 
Juli 2018 dari: https://media.neliti.com/media/publications/74110-ID-pengaruhperilaku-konsumen-terhadap-kepu.pdf.

[6] Kotler, P. (2003) Manajemen Pemasaran. Terjemahan: Bob Sabran. Jakarta: Erlangga.

[7] Mohamad, N. and Backhouse, C. (2014) A Framework for the Development of Halal Food Products inMalaysia. Proceeding International Conference on Industrial Engineering and Operations Management. Bali. January 7-9th, 2014. pp. 693-702.

[8] Sugiyono. (2012). Metode Penelitian Kuantitatif, Kualitatif, dan $R$ \& D.Bandung: Alfabeta.

[9] Syah, N. H. (2017). Analisis Faktor-faktor yang Mempengaruhi Keputusan Pembelian melalui Online Shop di Kota Medan. Tesis Prodi Studi Ekonomi Islam UIN Sumatera Utara.

[10] Talati, Z., et.al. (2017). The Impact of Interpretive and ReductiveFront-of-Pack Labels on Food Choice andWillingness to Pay. International Journal of Behavioral Nutrition and Physical Activity. Vol. 14 (171). pp. 1-10.

[11] Zulaekah, S. and Kusumawati, Y. (2015) Halal dan Haram Makanan dalam Islam. $\begin{array}{lllll}\text { Dipetik } & \text { tanggal } & 28 & \text { Juli } & 2018\end{array}$ https://www.researchgate.net/publication/277226802. hlm. 25-35. 